DOI: $10.17516 / 1997-1370-0477$

УДК 796.011.3

\title{
Professional Competences of Physical Education Teachers: Structural and Component Analysis
}

\author{
Marina G. Yanova, Vladimir V. Yanov, \\ Sergey V. Kravchenko and Irina V. Vetrova* \\ Krasnoyarsk State Pedagogical University named after V.P. Astafiev \\ Krasnoyarsk, Russian Federation
}

Received 03.07.2019, received in revised form 06.09.2019, accepted 25.10.2019

\begin{abstract}
The article reveals the essence of the competency-based method in education and understanding of competence in general. The article examines the features of professional competence in general and professional competences of physical education teachers in particular. The component structure and the structure of professional competence of PE teachers is studied. The conditions (objective and subjective, external and internal) of the formation of professional competences of PE teachers are disclosed.
\end{abstract}

Keywords: pedagogical education, physical education, sport, professional competence, professional competence of a teacher, professional competence of physical education teachers.

Research area: theory and methodology of vocational education.

Citation: Yanova, M.G., Yanov, V.V., Kravchenko, S.V., Vetrova, I.V. (2019). Professional competences of physical education teachers: structural and component analysis. J. Sib. Fed. Univ. Humanit. Soc. Sci., 15(4), 554-558. DOI: 10.17516/1997-1370-0477.

\footnotetext{
(C) Siberian Federal University. All rights reserved

* Corresponding author E-mail address: ymg_boss@mail.ru ORCID: 0000-0003-4262-7015 (Yanova)
} 


\section{Introduction}

The transformation of Russian education to the standards of two-level education is accompanied by development of various competences in students and leads to the transition of modern transitive education to training specialists in the context of the competence approach (Yanova, Adolf, Ignatova, 2013: 177). This fully applies to training physical education teachers as professionals working in the field of balanced personality development and health preservation. Consideration of the structure of professional competences of PE teachers should begin with the study of the structure of professional competence in its general sense.

The competency-based approach in education involves not simply learning, but also emphasises the ability to effectively apply the knowledge gained in further professional activity. In Russia, within the framework of the competency-based approach, the "Strategy for Modernising the Content of General Education" has been adopted, which includes the main provisions of the competency-based approach in education, the key concept of which is competence (Strategia modernizatsii soderzhania..., 2001). The document emphasises that the concept of "competence" is broader than the concept of "knowledge" or "skill" because structurally, these concepts constitute competence (although, of course, we are not talking about competence as a simple sum of knowledge and skills).

Education, upbringing and development of students of a pedagogical university as future professionals, formation of their professional culture in the sense of their awareness of the need for cultural development is the most important element of the general pedagogical process. The practice of teachers' training confirms that the success of the implementation of any curriculum is correlated with the professionalism of a teacher and depends on their professional competence.

Discussion. Professional competencies are key and multifunctional (allowing to solve various problems in everyday, professional or social life). They stand above the subject and they are interdisciplinary (applicable in various situations, not only at school, but also at work, in the family, in the political sphere). They are multidimensional (including various mental processes and intellectual skills (analytical, critical, communicative), "know-how" and common sense (Strategia modernizatsii soderzhania..., 2001: 7).

Key competencies require significant intellectual development: abstract thinking, self-reflection, determining one's own position, self-esteem, critical thinking, and more.

The authors of the "Strategy..."payattention to the difficulties of assessing professional competencies as a result of training, since the concept of "competence" includes not only cognitive and operational-technological components, but also complements it with value-oriented, motivational, ethical, social and behavioural content (Strategia modernizatsii soderzhania..., 2001: 14), which is difficult to assess diagnostically. A.V. Khutorskoi appeals to the multidimensional and multi-functional features of the teachers' training process in the framework of the competency-based approach, which among the main key competencies highlights the following: value-sense, cultural, educational, informative, communicative, social and labour, and personal (Khutorskoi, 2002). In order to somehow order the subsequent interpretation of competences, the developers of the "Strategy for Modernising the Content of General Education" propose a division of competences by areas, assuming that the structure of key competencies should include: competence in the field of independent cognitive activity; competence in civil and social activities; competence in the field of social and labour activities (including the ability to understand and apply the norms and ethics of relationships, self-organization skills); competence in the household sphere; and competence in the field of cultural and leisure activities" (Strategia modernizatsii soderzhania..., 2001: 15).

Thus, the goal of the modernised transitive education is to develop graduate's competencies and within the framework of pedagogical education and training of a future teacher to form their professional pedagogical competencies, including general cul- 
tural and professional competences, as well as particular professional and cultural competences. Let us now consider these competences.

The study of professional competences is impossible without considering competence in its general meaning. M.A. Choshanov states that "competence is a fundamentally new quality of teachers' training, which determines a high level of qualification and professionalism of a specialist" (Khutorskoi, 2002). The researcher outlines that competence is a specific quality that characterises a set of professional knowledge and skills:

- knowledge of a competent teacher is constantly updated, is up-to-date and flexible;

- competence reflects the unity and connection of the substantive component - knowledge and procedural one - skills;

- competence assumes the optimal choice in solving situations in professional activities and justifying this choice (critical thinking).

Therefore, the professional competence of a teacher is considered as a balanced combination of knowledge and skills acquired in the process of training; methods and techniques for the implementation of educational programmes in culture-making pedagogical activities; cultural development and self-development of a teacher; their skills and readiness to find and implement creative solutions in various educational situations; to accumulate and transmit cultural pedagogical experience. In other words, a teacher should be qualified in the field of application and manifestation of their professional competence.

The state standard of higher education determines that professional competenceы of a teacher include general professional competencies (GPC) that characterise the level of the subject knowledge and skills in the field of profession, i.e. basic knowledge of the subject, and professional competencies (PC), which determine the level of special competencies that are characteristic only for this area of the profession.

The structure of the teacher's professional competences in general sense and of the PE teacher in particular, is determined not only by basic professional knowledge and skills, but also by the system of values in the profession, characterising their incentives and preferences, the ability to value knowledge, experience, and relationships with people in the profession. Incentives and preferences that encourage teaching determine the effectiveness and efficiency of this activity. Fulfilling themselves in the profession, a competent teacher constantly seeks professional growth, self-education, self-organization and self-expression. Penetration into the essential part of the prefix "self ..." explains that it is a question of developing "oneself", of the readiness to show one's best personal characteristics and professional qualities (Yanova, 2012: 63-73).

Defining the work of PE teachers as a social task which should contribute to the development of a harmonious personality brought up in cultural modes of individual and social behaviour, we understand that these settings of the profession are transferred and transformed into an individual attitude that each teacher seeks to fulfill in their profession. The teacher's creativity and professionalism are fully projected on the student's personality only if the teacher has a profound knowledge of the subject taking into account developmental psychology, theoretical knowledge in the field of physical education, methodological knowledge and recommendations, knowledge in the field of forecasting and planning their professional activities (Yanova, 2012: 63-73).

Studying the professional competences of PE teachers, we draw attention to the fact that physical education is part of the general culture of a person and, in turn, structurally fills the professional competence of a teacher in its general sense. Thus, dividing the professional competences of PE teachers into structural elements, we should clarify that these competences are the key ones in preparing a modern teacher for professional activity, and include all the components of general competences supplemented by specific components.

Turning to the detailed analysis of the professional competences of PE teachers, let us note that teacher's professionalism in this area is fully projected on the student's personality only if the teacher has a deep knowledge in the professional field that covers all areas of the "physical education" subject. At the same 
time, subject knowledge is not limited to the knowledge of the subject only, but is formed taking into account:

- knowledge of general and developmental psychology;

- knowledge of disciplines in medical-biological and physiological fields;

- theoretical knowledge in the field of physical education in the context of knowledge of basic, new and national types of sports;

- methodological knowledge and recommendations on its use for planning lessons and regulating exercise load in PE classes;

- knowledge in the field of health protection and hygiene;

- knowledge in the field of forecast and design of their professional activities;

- knowledge of obtaining best practice in the field of physical education and sports.

The structure of the professional competences of PE teachers includes the following personal features which are taken as optimal for this professional profile:

- spiritual culture;

- interaction with students based on agreement and mutual understanding;

- knowledge of creative innovative methods and technologies;

- readiness for self-education and self-perfection;

- creative self-expression in the selection and development of methods and tools used in the class, which characterises the teacher as culture-creating; characterises their ability to follow cultural patterns of behaviour and learn the cultural practices of other teachers and trainers;

- teacher's creative abilities expressed in readiness to improve "oneself"; to improve sets of exercises; to develop new techniques; to develop and apply physical education and sports programmes; to develop the concepts of les- sons, sports competitions, mass sports holidays and more.

Moreover, the development of the professional competences of PE teachers is determined by the integrability of conditions (objective and subjective, external and internal) and is due to the need for continuous teacher's training in the context of their self-education and additional professional education aimed at developing their professional competence.

Taking into account the current features of the educational process, it is necessary to pay attention to the fact that a physical education teacher must possess competencies in the field of not only basic sports (an approximate programme of basic general education in physical education), but also new ones; as well as sports that reflect national and regional specificity.

\section{Conclusion}

The component and structural analysis of the professional competences of PE teachers provides the basis for concluding that these competences are a combination of the following components: knowledge and skills in the field of the profession in general, and in the field of physical education and sports, in particular; experience in the unity and interconnection of the teacher's spiritual, value, interactive and creative manifestations; personal qualities; and motivation. Each component of the PE teacher's professional competences is characterised by the aspects of their manifestation and is considered in the context of ongoing professional activities.

The studied professional competence is formed in the situation of integrative unity and interconnection of conditions (objective and subjective, external and internal), regular teacher's training in the context of self-education, self-improvement and additional professional education.

\section{References}

Adolf, V., Yanova, M., Kondratyuk, T., Strogova, N., Zaitseva, M. (2017). Otsenka konkurentosposobnosti vypusknika pedagogicheskogo universitets s pozitsii rabotodatelia. Krasnoyarsk. In Krasnoyarsk State Pedagogical University named after V.P. Astafyev, 32-38.

Strategia modernizatsii soderzhania obchshego obrazovania (2001). In Materialy dlia razrabotki dokumentov po obnovleniiu obchshego obrazovania. Moskva. 
Khutorskoi, A. (2002). Kliuchevyie kompetentsii I obrazovatelnyie standarty. Doklad na otdelenii fylosofii obrazovania I teorii pedagogiki RAO. In Tsentr «Eidos». Available at: www/eidos.ru/news/compet $/ \mathrm{htm}$

Choshanov, M. (1996). Gibkaia tehnologiia problemno-modulnogo obucheniia. Moskva.

Yanova, M., Adolf, V., Ignatova, V. (2013). Pedagogicheskoie obrazovatelnyie: tranzitivnyie kharakteristiki. In Nauchnoie Mneniie, 4, 177-182.

Yanova, M. (2012). Structura professionalmoi competentsii pedagoga. In Pedagogicheskii zhurnal «Analitika Rodis», 63-73.

Yanova, M. (2015). Kulturnyi aspect professionalnoy podgotovki bakalavra fizicheskoy kultury. In Vestnik KGPU im. V.P. Astsfieva, 3, 112-117.

\title{
Профессиональная компетентность педагога по физической культуре: структурный и компонентный анализ
}

\section{М.Г. Янова, В.В.Янов, С.В. Кравченко, И.В. Ветрова}

Красноярский государственный педагогический университет им. В.П. Астафьева

Российская Федерация, Красноярск

\begin{abstract}
Аннотация. Статья раскрывает сущность компетентностного метода в образовании и компетенции в ее общем представлении. В статье изучаются особенности профессиональной компетенции как в общем представлении, так и в отношении учителя физической культуры. Исследуется компонентный состав и структура профессиональной компетентности педагога по физической культуре, а также раскрываются условия (объективные и субъективные, внешние и внутренние) ее формирования.
\end{abstract}

Ключевые слова: педагогическое образование, физическая культура, физическая культура и спорт, компетентностный подход, профессиональная компетентность педагога, структура и компонентный состав профессиональной компетентности педагога по физической культуре.

Научная специальность: 13.00 .08 - теория и методика профессионального образования. 